\title{
Modeling Pancreatic Endocrine Cell Adaptation and Diabetes in the Zebrafish
}

\author{
Lisette A. Maddison and Wenbiao Chen* \\ Department of Molecular Physiology and Biophysics, Vanderbilt University School of Medicine, Nashville, TN, USA
}

\section{OPEN ACCESS}

Edited by:

Yong Zhu,

East Carolina University, USA

Reviewed by:

Amnon Schlegel,

University of Utah, USA

Mary Kinkel,

Appalachian State University,

USA

*Correspondence: Wenbiao Chen wenbiao.chen@vanderbilt.edu

Specialty section: This article was submitted to Experimental Endocrinology,

a section of the journal

Frontiers in Endocrinology

Received: 29 November 2016 Accepted: 11 January 2017 Published: 26 January 2017

Citation:

Maddison LA and Chen W (2017) Modeling Pancreatic Endocrine Cell

Adaptation and Diabetes

in the Zebrafish.

Front. Endocrinol. 8:9.

doi: 10.3389/fendo.2017.00009
Glucose homeostasis is an important element of energy balance and is conserved in organisms from fruit fly to mammals. Central to the control of circulating glucose levels in vertebrates are the endocrine cells of the pancreas, particularly the insulin-producing $\beta$-cells and the glucagon producing $\alpha$-cells. A feature of $\alpha$ - and $\beta$-cells is their plasticity, an ability to adapt, in function and number as a response to physiological and pathophysiological conditions of increased hormone demand. The molecular mechanisms underlying these adaptive responses that maintain glucose homeostasis are incompletely defined. The zebrafish is an attractive model due to the low cost, high fecundity, and amenability to genetic and compound screens, and mechanisms governing the development of the pancreatic endocrine cells are conserved between zebrafish and mammals. Post development, both $\beta$ - and $\alpha$-cells of zebrafish display plasticity as in mammals. Here, we summarize the studies of pancreatic endocrine cell adaptation in zebrafish. We further explore the utility of the zebrafish as a model for diabetes, a relevant topic considering the increase in diabetes in the human population.

Keywords: zebrafish, glucose homeostasis, $\beta$-cell, $\alpha$-cell, plasticity, regeneration

\section{INTRODUCTION}

Glucose homeostasis is a central physiological mechanism important to maintain proper energy balance and cellular function. While the bulk of the information concerning glucose homeostasis comes from studies in mammals, homeostatic mechanisms are active in many organisms including teleost fish [reviewed in Ref. (1)], which underscores the importance of maintaining tight control of circulating glucose. Maintenance of glucose homeostasis is a coordinated effort between multiple organ systems including the brain, skeletal muscle, liver, and the pancreatic endocrine cells. By appropriately secreting glucagon and insulin into the circulation to regulate the production and uptake of blood glucose, respectively, the pancreatic $\alpha$ - and $\beta$-cells play a central role in glucose homeostasis. Interestingly, in conditions where demand for insulin or glucagon exceeds the current secretory capacity, glucose homeostasis is still maintained through increased function and number of $\alpha$ - or $\beta$-cells. The regulatory mechanisms of this adaptation or compensation, particularly the compensatory increase of cell number, are not fully defined.

The zebrafish has been firmly established as an attractive animal model to explore questions in developmental biology. This has been aided by the low cost, high fecundity traits of the model (2) as well as the optical transparency (3-6), ease of genome manipulation (7-10), and the amenability toward small molecule screens (11-13). These attractive traits of zebrafish have also inspired investigators to study other biological questions including glucose homeostasis. 


\section{GLUCOSE HOMEOSTASIS IN ZEBRAFISH}

The systems regulating glucose homeostasis in zebrafish are similar to those of mammals in composition, ontogeny, and function. As in mammals, glucose homeostasis in zebrafish involves brain, skeletal muscle, liver, and the pancreatic endocrine cells. For example, the glucose transporter Glut2 has been found to be critical for proper brain development (14) supporting the importance of appropriate glucose control in the brain. In skeletal muscle, glucose transporters are present (15) and glucose uptake has been found to be insulin sensitive (16), suggesting that like in mammals, skeletal muscle is a major site of glucose disposal. The liver has a critical function in glucose homeostasis as it both uses and produces glucose. Gluconeogenesis is dynamically regulated in the zebrafish liver (17), and glucose-regulated $p c k$ promoter activity has been leveraged to screen for compounds that impact glucose production (18). Furthermore, risk alleles for altered fasting blood glucose in humans have been found to increase gluconeogenesis in the liver (19). This again supports the conservation of regulatory pathways of glucose homeostasis. Coordinating many aspects of glucose homeostasis are the pancreatic endocrine cells. Of primary focus has been the insulinproducing $\beta$-cells and the glucagon-producing $\alpha$-cells. In the zebrafish, these cells are present as early as 1 day post fertilization and their development is regulated by pathways similar to those for mammals (20-22). The conservation of glucose homeostasis system between zebrafish and mammals supports that zebrafish is a relevant model to study mechanisms of glucose homeostasis, including aspects of pancreatic endocrine cell biology.

\section{PROMOTING $\beta$-CELL PROLIFERATION AND DIFFERENTIATION IN LARVAL STAGES WITH SMALL MOLECULES: LINEAGES AND PATHWAYS}

Replenishing the $\beta$-cell mass has been an active area of investigation for many years as approaches to treat both type 1 and type 2 diabetes. To increase $\beta$-cells in adults, often the approach is to manipulate pathways active during development. But there is also a need to understand the mechanisms that promote an increase of $\beta$-cells post development, either through neogenesis or through increased proliferation as different mechanisms may be active for adaption to changes in physiology. In embryonic and early larval stages, the pancreatic endocrine cells are primarily coalesced in a single large islet referred to as the principal islet (23). At later larval stages, additional secondary islets are present (24). These secondary islets arise from centroacinar cells in the pancreatic duct (24-28). These cells are Notch sensitive $(24,25,28)$ and express markers of endocrine precursors including Nkx6.1 (26) and Nkx2.2 (25). Inducing formation of secondary islets as a way to uncover pathways important in stages beyond early development was the basis of a compound screen $(29,30)$ and a component of another large-scale screen (30). These screens took advantage of the optical transparency of the zebrafish and transgenic lines that mark the pancreatic endocrine cells. The first screen revealed an important role for retinoic acid signaling in the differentiation of endocrine progenitors (29). Follow-up studies have shown this pathway is functionally conserved in humans (31) and that retinoic acid signaling regulated Sox9b (32), an important transcription factor in endocrine cell differentiation (33). The high-throughput screen was based on increasing endocrine cells in both the principal and secondary islets and yielded several candidate pathways controlling endocrine cell differentiation including NFKB signaling and serotonin signaling (30). Both screens captured changes in both proliferation of endocrine cells and differentiation of precursors. Another compound screen aimed solely to increase $\beta$-cell proliferation (34) and relied on expression of markers indicative of the different phases of the cell cycle (35). This screen also identified retinoic acid and serotonin signaling, as well as glucocorticoids, as regulators of proliferation (34). These compound-screening approaches identified both molecules with functions in development, such as Sox9, and also pathways such as serotonin and NFKB which likely also function in post-developmental stages. Ultimately, these compound screening approaches using zebrafish may provide molecules that can be targeted to increase $\beta$-cell mass as a treatment for adults with diabetes.

\section{PANCREATIC ENDOCRINE CELL PLASTICITY IN RESPONSE TO INSUFFICIENT HORMONE ACTION}

Proper development of the pancreatic endocrine cells is unquestionably crucial to establish homeostatic control. But equally important is understanding the underlying mechanisms that allow adaptation to different physiological stresses, in other words, plasticity. For example, in mammals, the $\beta$-cell mass increases during pregnancy $(36,37)$, with high-fat diet in mice (38-40), and in non-diabetic obese humans $(41,42)$. With obesity the increase in $\beta$-cell mass is an adaptive mechanism to compensate for insulin resistance (43). In type 2 diabetic obese patients, the $\beta$-cell mass is decreased compared to non-diabetic counterparts $(41,44)$, which has been attributed to $\beta$-cell death or dedifferentiation, in other words, the loss of $\beta$-cell identity (45-47). Zebrafish have been shown to also have $\beta$-cell compensatory responses. For example, in states of overnutrition, through culturing in glucose solution or in chicken egg yolk emulsion, the number of $\beta$-cells increases (48-53). This treatment also causes $\beta$-cell increase in older larvae (52). In juvenile fish, a high calorie diet can promote $\beta$-cell proliferation and secondary islet formation (54), indicating that the overnutrition-induced $\beta$-cell expansion is not limited only to early larval stages. The compensatory increase in $\beta$-cells did not occur with intermittent exposure to the same diets, as would be found in meal-type feeding (52). Consistent with overnutrition as the trigger for the compensatory response, the expansion of the $\beta$-cells has been found to be dependent on the nutrient-secretion coupling apparatus in preexisting $\beta$-cells (49). Stimulating $\beta$-cell secretion through pharmacologic or genetic means increased the number of $\beta$-cells in the absence of overnutrition (49). Conversely, reducing $\beta$-cell activity inhibited the $\beta$-cell expansion in the presence of overnutrition (49). The rapid expansion of $\beta$-cells was not through stimulation of $\beta$-cell proliferation $(49,52)$ 
based on incorporation of EdU, which suggested differentiation of resident precursors. Lineage tracing experiments indicated that these new cells did not arise from the centroacinar cells in the pancreatic duct (50) but arise from cells with $m n x 1$ and $n k x 2.2$ promoter activity $(50,52)$ likely residing within the principal islet. The non-canonically secreted FGF1 has been proposed to be a candidate molecule stimulating differentiation of these resident endocrine precursors (50). Mutation of $f g f 1$ abolished the overnutrition-induced $\beta$-cell expansion but did not alter the baseline $\beta$-cell number, and this could be rescued through transgenic expression of human FGF1 (50). Furthermore, when FGF1 was altered to allow for secretion through the canonical secretion pathway, the basal number of $\beta$-cells was increased without overnutrition stimulation (50). Intact leptin signaling is important for these responses (53) as leptin receptor mutant larvae had a higher number of $\beta$-cells developmentally but did not increase number of $\beta$-cells with high-fat diet feeding. In addition, blocking insulin expression through morpholino injection or through expression of a dominant-negative IRS2 protein increased the number of $\beta$-cells during embryonic stages (55). Furthermore, in adult fish with skeletal muscle insulin resistance, there was an initial increase in the number of $\beta$-cells (16). These studies suggest that with an increased need for insulin function, either due to elevated nutrient intake or through inhibition of insulin signaling, zebrafish increase the number of $\beta$-cells as an adaptive mechanism, similar to what has been observed in mammals. These conserved responses indicate that zebrafish are a useful model to study $\beta$-cell adaptive mechanisms, and with the utility of zebrafish in genetic and pharmacological approaches, the role of candidate molecules, such as FGF1, can be rapidly assessed.

Although $\beta$-cells are often the focus in glucose homeostasis, the glucagon-producing $\alpha$-cells also have an important role in modulating glucose production. Glucagon acts as a counterregulatory hormone to insulin, and modulating glucagon signaling is becoming an increasingly attractive approach for diabetic treatments (56). It has been found in mice that the number of $\alpha$-cells increases with blockade of glucagon signaling either by knocking out glucagon, the glucagon receptor, or Gs $\alpha$, or by impairing glucagon receptor function with antagonists or monoclonal antibody treatment (57-61). With the $\beta$-cells, this suggests an adaptive response to the decreased effectiveness of glucagon. This is also true in zebrafish, where mutation of the two glucagon receptors resulted in an increased number of $\alpha$-cells (62). The adaptive responses to nutritional or hormonal status in both $\beta$-cells and $\alpha$-cells reflect conservation of metabolic responses between mammals and zebrafish. This further indicates that pathways and molecules identified in zebrafish may indeed be relevant to mammals.

\section{ROBUST $\beta$-CELL REGENERATION FOLLOWING ABLATION}

Another aspect of the plasticity of pancreatic endocrine cells is regeneration following ablation. Zebrafish has tremendous regenerative capacities, including the $\beta$-cells. Similar to compensatory increase of $\beta$-cell mass, ablation-induced regeneration is also a response to unmet insulin demand, inferred by the high free glucose levels following ablation $(25,34,63,64)$ and underscores the conservation of $\beta$-cell function in zebrafish. Most commonly in zebrafish, $\beta$-cells are ablated through $\beta$-cell-specific expression of bacterial nitroreductase that converts the prodrug metronidazole to a genotoxic metabolite, resulting in death of the cells (65). There have been other approaches however, including inducible expression of a truncated Bid protein, tBid (49), and mosaic expression of diphtheria toxin (DTA) (66) in larval zebrafish as well as streptozotocin (STZ) treatment in adult fish $(67,68) . \beta$-cell regeneration occurs quickly following ablation $(25,65,69,70)$ and has been used as an approach to identify sources of new $\beta$-cells. Using lineage tracing in adult fish where $\beta$-cells were ablated through nitroreductase/metronidazole, it was determined that the centroacinar cells residing in the pancreatic duct are the primary source of new $\beta$-cells based on promoter activity of $n k x 6.1$ (26) or through Notch responsiveness (25). Ablation of $\beta$-cells in larval zebrafish also identified that transdifferentiation of $\alpha$-cells to $\beta$-cells contributes to regeneration $(55,63,64)$. Using a combination of pharmacological and morpholino approaches, the $\alpha$-cell transdifferentiation was found to be dependent on glucagon but not through the modulation of gluconeogenesis (64). This seems to differ from mouse where $\alpha$ - to $\beta$-cell transdifferentiation is independent of glucagon signaling (71). The secreted factor IGFBP1 has been found to also enhance $\alpha$ - to $\beta$-transdifferentiation following ablation (63). Regeneration following ablation has also been used to identify compounds that increase regeneration (70). This study identified a compound that activates adensosine GPCR to increase proliferation. Interestingly, this compound had a limited capacity to induce $\beta$-cell proliferation during development, which may reflect the difference between embryonic immature $\beta$-cells and mature $\beta$-cells. These studies provide important insights into the origins of and specific pathways leading to new $\beta$-cells and exemplify the plasticity of pancreatic endocrine cells. The ablation and recovery studies also exemplify the robust regenerative capacity of zebrafish that is not fully recapitulated in mammalian models. $\beta$-cell ablation in mouse using STZ, pancreatic ligation, and partial pancreatectomy causes less robust regeneration (72-77). Understanding the keys that confer the regenerative capacity of zebrafish may provide avenues to boost the regenerative potential in mammals.

\section{MODELING DIABETES IN THE ZEBRAFISH}

It is always of interest to produce an animal model that accurately reflects a human disease. While studies in zebrafish have been extremely useful to identify molecules, pathways, and cell types that contribute to the plasticity of the pancreatic endocrine cells, to date there have been no models that accurately reflect the life history of a human with diabetes. This is exclusive of models reflecting the maturity-onset forms of diabetes including targeting NeuroD that models MODY6 (78), Pdx1 that models MODY4 (48), and Hnflba that models MODY5 (79). However, these forms of diabetes are quite rare in the overall patient population (80). The approaches to mimic type 1 diabetes by ablating $\beta$-cells have highlighted the regenerative nature of zebrafish, and 
hyperglycemia is quickly reversed. Although stable expression of DTA can eliminate all $\beta$-cells, these fish have growth retardation and fail to thrive (54). For modeling type 2 diabetes, genetically induced muscle insulin resistance using dominant-negative IGF1 receptor (dnIGFR) expression only resulted in glucose intolerance in aged fish but no elevation in fasting blood glucose (16). Likewise, mutation of insulin receptors specifically in the liver resulted in postprandial alterations in glucose (10) but fasting blood glucose was reduced, similar to the liver insulin receptor knockout mice (81). Overfeeding adult fish quickly results in increased fasting glucose $(16,82)$ but hyperglycemia was reversed by returning to normal feeding. Although zebrafish are glucose sensitive $(16,83)$, insulin resistance or overfeeding in and of itself may be insufficient to lead to gross dysfunction of glucose homeostasis. A better understanding of the physiology of glucose control in zebrafish is likely necessary for the development of a truly diabetic zebrafish.

Despite the current lack of a robust model for diabetes, the zebrafish stands to contribute to the understanding of the influence of T2D-associated genetic loci on $\beta$-cell mass. Genome-wide association studies have identified loci associated with diabetes risk. The challenge is to determine the relevance of these different loci to phenotypes including $\beta$-cell mass and $\beta$-cell function and further determine the genes that may be influenced by these loci. Given the genetic tractability, the ease of producing mutations via CRISPR/Cas9, and the proven islet cell plasticity, zebrafish are an extremely attractive model to investigate the role of these candidate loci. Recently, O'Hare et al. examined 67 candidate genes from GWAS studies using morpholino and CRISPR-based approaches (84). The impact on $\beta$-cell number and regeneration was assayed, and 25 genes that reduced $\beta$-cell number when mutated were found. This included genes previously known to influence $\beta$-cell number such as $p d x 1$ and pax4 as well as some new genes such as camk1d. This study, as well as those using genes

\section{REFERENCES}

1. Polakof S, Mommsen TP, Soengas JL. Glucosensing and glucose homeostasis: from fish to mammals. Comp Biochem Physiol B Biochem Mol Biol (2011) 160(4):123-49. doi:10.1016/j.cbpb.2011.07.006

2. Kimmel CB, Ballard WW, Kimmel SR, Ullmann B, Schilling TF. Stages of embryonic development of the zebrafish. Dev Dyn (1995) 203(3):253-310. doi:10.1002/aja.1002030302

3. Zeituni EM, Farber SA. Studying lipid metabolism and transport during zebrafish development. In: Kawakami K, Patton EE, Orger M, editors. Zebrafish: Methods and Protocols. New York, NY: Springer (2016). p. 237-55.

4. Herrgen L, Schröter C, Bajard L, Oates AC. Multiple embryo time-lapse imaging of zebrafish development. In: Lieschke GJ, Oates AC, Kawakami K, editors. Zebrafish: Methods and Protocols. Totowa, NJ: Humana Press (2009). p. 243-54.

5. Hall C, Flores MV, Crosier K, Crosier P. Live cell imaging of zebrafish leukocytes. In: Lieschke GJ, Oates AC, Kawakami K, editors. Zebrafish: Methods and Protocols. Totowa, NJ: Humana Press (2009). p. 255-71.

6. Feierstein CE, Portugues R, Orger MB. Seeing the whole picture: a comprehensive imaging approach to functional mapping of circuits in behaving zebrafish. Neuroscience (2015) 296:26-38. doi:10.1016/j.neuroscience.2014.11.046

7. Ni TT, Lu J, Zhu M, Maddison LA, Boyd KL, Huskey L, et al. Conditional control of gene function by an invertible gene trap in zebrafish. Proc Natl Acad Sci U S A (2012) 109(38):15389-94. doi:10.1073/pnas.1206131109 underlying monogenic forms of diabetes, supports the utility of zebrafish as a model to study the genetic basis of the disease.

To date, all of the screening modalities have relied on measuring changes in the physical number of the $\beta$-cells. While secondary measures have also examined free glucose $(30,34,84)$, no primary screen has been done to assay for $\beta$-cell function either in parallel or instead of changes in cell number. Approaches to achieve this end are currently lacking. Examining calcium signaling through expression of genetically encoded sensors of calcium activity is one approach that may be useful (85), although difficult to employ in a high-throughput screen. To fully understand the physiology of glucose control in the zebrafish, other assays should be developed, beyond those that rely on cell numbers and free glucose assays.

Given all these measures, studies using zebrafish clearly have contributed to the study of glucose homeostasis. From endocrine cell development, plasticity under different conditions, genetic susceptibility, to modeling diabetes, the zebrafish has and will continue to have utility. With the ever increasing number of patients with diabetes, applying as many resources and approaches can only serve to increase knowledge and provide new avenues for therapies.

\section{AUTHOR CONTRIBUTIONS}

All authors listed have made substantial, direct, and intellectual contribution to the work and approved it for publication.

\section{ACKNOWLEDGMENTS}

This work was supported by the Vanderbilt Diabetes Research and Training Center, the National Institutes of Health DK088686 (WC), and the American Diabetes Association 1-13-BS-027 (WC).

8. Yin L, Maddison LA, Chen W. Multiplex conditional mutagenesis in zebrafish using the CRISPR/Cas system. Methods Cell Biol (2016) 135:3-17. doi:10.1016/ bs.mcb.2016.04.018

9. Kikuta H, Kawakami K. Transient and stable transgenesis using Tol2 transposon vectors. In: Lieschke GJ, Oates AC, Kawakami K, editors. Zebrafish: Methods and Protocols. Totowa, NJ: Humana Press (2009). p. 69-84.

10. Yin L, Maddison LA, Li M, Kara N, LaFave MC, Varshney GK, et al. Multiplex conditional mutagenesis using transgenic expression of Cas 9 and sgRNAs. Genetics (2015) 200(2):431-41. doi:10.1534/genetics.115. 176917

11. White DT, Eroglu AU, Wang G, Zhang L, Sengupta S, Ding D, et al. ARQivHTS, a versatile whole-organism screening platform enabling in vivo drug discovery at high-throughput rates. Nat Protoc (2016) 11(12):2432-53. doi:10.1038/nprot.2016.142

12. Dang M, Fogley R, Zon LI. Identifying novel cancer therapies using chemical genetics and zebrafish. In: Langenau DM, editor. Cancer and Zebrafish: Mechanisms, Techniques, and Models. Cham: Springer (2016). p. 103-24.

13. Brady CA, Rennekamp AJ, Peterson RT. Chemical screening in zebrafish. In: Kawakami K, Patton EE, Orger M, editors. Zebrafish: Methods and Protocols. New York, NY: Springer (2016). p. 3-16.

14. Marin-Juez R, Rovira M, Crespo D, van der Vaart M, Spaink HP, Planas JV. GLUT2-mediated glucose uptake and availability are required for embryonic brain development in zebrafish. J Cereb Blood Flow Metab (2015) 35(1):74-85. doi:10.1038/jcbfm.2014.171 
15. Planas JV, Capilla E, Gutierrez J. Molecular identification of a glucose transporter from fish muscle. FEBS Lett (2000) 481(3):266-70. doi:10.1016/ S0014-5793(00)02020-2

16. Maddison LA, Joest KE, Kammeyer RM, Chen W. Skeletal muscle insulin resistance in zebrafish induces alterations in beta-cell number and glucose tolerance in an age- and diet-dependent manner. Am J Physiol Endocrinol Metab (2015) 308(8):E662-9. doi:10.1152/ajpendo.00441.2014

17. Jurczyk A, Roy N, Bajwa R, Gut P, Lipson K, Yang C, et al. Dynamic glucoregulation and mammalian-like responses to metabolic and developmental disruption in zebrafish. Gen Comp Endocrinol (2010) 170(2):334-45. doi:10.1016/j. ygcen.2010.10.010

18. Gut P, Baeza-Raja B, Andersson O, Hasenkamp L, Hsiao J, Hesselson D, et al. Whole-organism screening for gluconeogenesis identifies activators of fasting metabolism. Nat Chem Biol (2013) 9(2):97-104. doi:10.1038/nchembio.1136

19. Karanth S, Zinkhan EK, Hill JT, Yost HJ, Schlegel A. FOXN3 regulates hepatic glucose utilization. Cell Rep (2016) 15(12):2745-55. doi:10.1016/ j.celrep.2016.05.056

20. Kimmel RA, Meyer D. Molecular regulation of pancreas development in zebrafish. Methods Cell Biol (2010) 100:261-80. doi:10.1016/B978-0-12384892-5.00010-4

21. Kinkel MD, Prince VE. On the diabetic menu: zebrafish as a model for pancreas development and function. Bioessays (2009) 31(2):139-52. doi:10.1002/ bies. 200800123

22. Tehrani Z, Lin S. Endocrine pancreas development in zebrafish. Cell Cycle (2011) 10(20):3466-72. doi:10.4161/cc.10.20.17764

23. Li Z, Wen C, Peng J, Korzh V, Gong Z. Generation of living color transgenic zebrafish to trace somatostatin-expressing cells and endocrine pancreas organization. Differentiation (2009) 77(2):128-34. doi:10.1016/j.diff.2008.09.014

24. Parsons MJ, Pisharath H, Yusuff S, Moore JC, Siekmann AF, Lawson N, et al. Notch-responsive cells initiate the secondary transition in larval zebrafish pancreas. Mech Dev (2009) 126(10):898-912. doi:10.1016/j.mod.2009.07.002

25. Delaspre F, Beer RL, Rovira M, Huang W, Wang G, Gee S, et al. Centroacinar cells are progenitors that contribute to endocrine pancreas regeneration. Diabetes (2015) 64(10):3499-509. doi:10.2337/db15-0153

26. Ghaye AP, Bergemann D, Tarifeno-Saldivia E, Flasse LC, Von Berg V, Peers $B$, et al. Progenitor potential of nkx6.1-expressing cells throughout zebrafish life and during beta cell regeneration. BMC Biol (2015) 13:70. doi:10.1186/ s12915-015-0179-4

27. Wang Y, Rovira M, Yusuff S, Parsons MJ. Genetic inducible fate mapping in larval zebrafish reveals origins of adult insulin-producing beta-cells. Development (2011) 138(4):609-17. doi:10.1242/dev.059097

28. Beer RL, Parsons MJ, Rovira M. Centroacinar cells: at the center of pancreas regeneration. Dev Biol (2016) 413(1):8-15. doi:10.1016/j.ydbio.2016.02.027

29. Rovira M, Huang W, Yusuff S, Shim JS, Ferrante AA, Liu JO, et al. Chemical screen identifies FDA-approved drugs and target pathways that induce precocious pancreatic endocrine differentiation. Proc Natl Acad Sci U S A (2011) 108(48):19264-9. doi:10.1073/pnas.1113081108

30. Wang G, Rajpurohit SK, Delaspre F, Walker SL, White DT, Ceasrine A, et al. First quantitative high-throughput screen in zebrafish identifies novel pathways for increasing pancreatic beta-cell mass. eLife (2015) 4:1-26. doi:10.7554/ eLife. 08261

31. Huang W, Wang G, Delaspre F, Vitery Mdel C, Beer RL, Parsons MJ. Retinoic acid plays an evolutionarily conserved and biphasic role in pancreas development. Dev Biol (2014) 394(1):83-93. doi:10.1016/j.ydbio.2014.07.021

32. Huang W, Beer RL, Delaspre F, Wang G, Edelman HE, Park H, et al. Sox $9 b$ is a mediator of retinoic acid signaling restricting endocrine progenitor differentiation. Dev Biol (2016) 418(1):28-39. doi:10.1016/j.ydbio.2016.08.019

33. Seymour PA, Freude KK, Tran MN, Mayes EE, Jensen J, Kist R, et al. SOX9 is required for maintenance of the pancreatic progenitor cell pool. Proc Natl Acad Sci U S A (2007) 104(6):1865-70. doi:10.1073/pnas.0609217104

34. Tsuji N, Ninov N, Delawary M, Osman S, Roh AS, Gut P, et al. Whole organism high content screening identifies stimulators of pancreatic betacell proliferation. PLoS One (2014) 9(8):e104112. doi:10.1371/journal.pone. 0104112

35. Sugiyama M, Sakaue-Sawano A, Iimura T, Fukami K, Kitaguchi T, Kawakami $\mathrm{K}$, et al. Illuminating cell-cycle progression in the developing zebrafish embryo. Proc Natl Acad Sci U S A (2009) 106(49):20812-7. doi:10.1073/ pnas.0906464106
36. Ackermann AM, Gannon M. Molecular regulation of pancreatic beta-cell mass development, maintenance, and expansion. J Mol Endocrinol (2007) 38(1-2):193-206. doi:10.1677/JME-06-0053

37. Bouwens L, Rooman I. Regulation of pancreatic beta-cell mass. Physiol Rev (2005) 85(4):1255-70. doi:10.1152/physrev.00025.2004

38. Terauchi Y, Takamoto I, Kubota N, Matsui J, Suzuki R, Komeda K, et al. Glucokinase and IRS-2 are required for compensatory beta cell hyperplasia in response to high-fat diet-induced insulin resistance. J Clin Invest (2007) 117(1):246-57. doi:10.1172/JCI17645

39. Mosser RE, Maulis MF, Moulle VS, Dunn JC, Carboneau BA, Arasi K, et al. High-fat diet-induced beta-cell proliferation occurs prior to insulin resistance in C57Bl/6J male mice. Am J Physiol Endocrinol Metab (2015) 308(7):E573-82. doi:10.1152/ajpendo.00460.2014

40. Stamateris RE, Sharma RB, Hollern DA, Alonso LC. Adaptive beta-cell proliferation increases early in high-fat feeding in mice, concurrent with metabolic changes, with induction of islet cyclin D2 expression. Am J Physiol Endocrinol Metab (2013) 305(1):E149-59. doi:10.1152/ajpendo.00040.2013

41. Hanley SC, Austin E, Assouline-Thomas B, Kapeluto J, Blaichman J, Moosavi M, et al. \{beta\}-cell mass dynamics and islet cell plasticity in human type 2 diabetes. Endocrinology (2010) 151(4):1462-72. doi:10.1210/en.2009-1277

42. Saisho Y, Butler AE, Manesso E, Elashoff D, Rizza RA, Butler PC. Beta-cell mass and turnover in humans: effects of obesity and aging. Diabetes Care (2013) 36(1):111-7. doi:10.2337/dc12-0421

43. Sachdeva MM, Stoffers DA. Minireview: meeting the demand for insulin: molecular mechanisms of adaptive postnatal beta-cell mass expansion. Mol Endocrinol (2009) 23(6):747-58. doi:10.1210/me.2008-0400

44. Rahier J, Guiot Y, Goebbels RM, Sempoux C, Henquin JC. Pancreatic beta-cell mass in European subjects with type 2 diabetes. Diabetes Obes Metab (2008) 10(Suppl 4):32-42. doi:10.1111/j.1463-1326.2008.00969.x

45. Butler AE, Janson J, Bonner-Weir S, Ritzel R, Rizza RA, Butler PC. Beta-cell deficit and increased beta-cell apoptosis in humans with type 2 diabetes. Diabetes (2003) 52(1):102-10. doi:10.2337/diabetes.52.1.102

46. Cinti F, Bouchi R, Kim-Muller JY, Ohmura Y, Sandoval PR, Masini M, et al. Evidence of beta-cell dedifferentiation in human type 2 diabetes. JClin Endocrinol Metab (2016) 101(3):1044-54. doi:10.1210/jc.2015-2860

47. Rhodes CJ. Type 2 diabetes - a matter of beta-cell life and death? Science (2005) 307(5708):380-4. doi:10.1126/science.1104345

48. Kimmel RA, Dobler S, Schmitner N, Walsen T, Freudenblum J, Meyer D. Diabetic pdx1-mutant zebrafish show conserved responses to nutrient overload and anti-glycemic treatment. Sci Rep (2015) 5:14241. doi:10.1038/ srep14241

49. Li M, Maddison LA, Page-McCaw P, Chen W. Overnutrition induces betacell differentiation through prolonged activation of beta-cells in zebrafish larvae. Am J Physiol Endocrinol Metab (2014) 306(7):E799-807. doi:10.1152/ ajpendo.00686.2013

50. Li M, Page-McCaw P, Chen W. FGF1 mediates overnutrition-induced compensatory beta-cell differentiation. Diabetes (2016) 65(1):96-109. doi:10.2337/ db15-0085

51. Lodh S, Hostelley TL, Leitch CC, O'Hare EA, Zaghloul NA. Differential effects on beta-cell mass by disruption of Bardet-Biedl syndrome or Alstrom syndrome genes. Hum Mol Genet (2016) 25(1):57-68. doi:10.1093/hmg/ddv447

52. Maddison LA, Chen W. Nutrient excess stimulates beta-cell neogenesis in zebrafish. Diabetes (2012) 61(10):2517-24. doi:10.2337/db11-1841

53. Michel M, Page-McCaw PS, Chen W, Cone RD. Leptin signaling regulates glucose homeostasis, but not adipostasis, in the zebrafish. Proc Natl Acad Sci US A (2016) 113(11):3084-9. doi:10.1073/pnas.1513212113

54. Ninov N, Hesselson D, Gut P, Zhou A, Fidelin K, Stainier DY. Metabolic regulation of cellular plasticity in the pancreas. Curr Biol (2013) 23(13):1242-50. doi:10.1016/j.cub.2013.05.037

55. Ye L, Robertson MA, Mastracci TL, Anderson RM. An insulin signaling feedback loop regulates pancreas progenitor cell differentiation during islet development and regeneration. Dev Biol (2016) 409(2):354-69. doi:10.1016/j. ydbio.2015.12.003

56. Davidson JA, Holland WL, Roth MG, Wang MY, Lee Y, Yu X, et al. Glucagon therapeutics: dawn of a new era for diabetes care. Diabetes Metab Res Rev (2016) 32(7):660-5. doi:10.1002/dmrr.2773

57. Gelling RW, Du XQ, Dichmann DS, Romer J, Huang H, Cui L, et al. Lower blood glucose, hyperglucagonemia, and pancreatic alpha cell hyperplasia 
in glucagon receptor knockout mice. Proc Natl Acad Sci U S A (2003) 100(3):1438-43. doi:10.1073/pnas.0237106100

58. Longuet C, Robledo AM, Dean ED, Dai C, Ali S, McGuinness I, et al. Liverspecific disruption of the murine glucagon receptor produces alpha-cell hyperplasia: evidence for a circulating alpha-cell growth factor. Diabetes (2013) 62(4):1196-205. doi:10.2337/db11-1605

59. Yu R, Dhall D, Nissen NN, Zhou C, Ren SG. Pancreatic neuroendocrine tumors in glucagon receptor-deficient mice. PLoS One (2011) 6(8):e23397. doi:10.1371/journal.pone.0023397

60. Chen M, Gavrilova O, Zhao WQ, Nguyen A, Lorenzo J, Shen L, et al. Increased glucose tolerance and reduced adiposity in the absence of fasting hypoglycemia in mice with liver-specific Gs alpha deficiency. J Clin Invest (2005) 115(11):3217-27. doi:10.1172/JCI24196

61. Solloway MJ, Madjidi A, Gu C, Eastham-Anderson J, Clarke HJ, Kljavin N, et al. Glucagon couples hepatic amino acid catabolism to mTOR-dependent regulation of alpha-cell mass. Cell Rep (2015) 12(3):495-510. doi:10.1016/ j.celrep.2015.06.034

62. Li M, Dean ED, Zhao L, Nicholson WE, Powers AC, Chen W. Glucagon receptor inactivation leads to alpha-cell hyperplasia in zebrafish. J Endocrinol (2015) 227(2):93-103. doi:10.1530/JOE-15-0284

63. Lu J, Liu KC, Schulz N, Karampelias C, Charbord J, Hilding A, et al. IGFBP1 increases beta-cell regeneration by promoting alpha- to beta-cell transdifferentiation. EMBO J (2016) 35(18):2026-44. doi:10.15252/embj.201592903

64. Ye L, Robertson MA, Hesselson D, Stainier DY, Anderson RM. Glucagon is essential for alpha cell transdifferentiation and beta cell neogenesis. Development (2015) 142(8):1407-17. doi:10.1242/dev.117911

65. Pisharath H, Rhee JM, Swanson MA, Leach SD, Parsons MJ. Targeted ablation of beta cells in the embryonic zebrafish pancreas using E. coli nitroreductase. Mech Dev (2007) 124(3):218-29. doi:10.1016/j.mod.2006.11.005

66. Li Z, Korzh V, Gong Z. DTA-mediated targeted ablation revealed differential interdependence of endocrine cell lineages in early development of zebrafish pancreas. Differentiation (2009) 78(4):241-52. doi:10.1016/j.diff.2009.05.009

67. Moss JB, Koustubhan P, Greenman M, Parsons MJ, Walter I, Moss LG. Regeneration of the pancreas in adult zebrafish. Diabetes (2009) 58(8):1844-51. doi: $10.2337 / \mathrm{db} 08-0628$

68. Olsen AS, Sarras MP Jr, Leontovich A, Intine RV. Heritable transmission of diabetic metabolic memory in zebrafish correlates with DNA hypomethylation and aberrant gene expression. Diabetes (2012) 61(2):485-91. doi:10.2337/ db11-0588

69. Anderson RM, Bosch JA, Goll MG, Hesselson D, Dong PD, Shin D, et al. Loss of Dnmt 1 catalytic activity reveals multiple roles for DNA methylation during pancreas development and regeneration. Dev Biol (2009) 334(1):213-23. doi:10.1016/j.ydbio.2009.07.017

70. Andersson O, Adams BA, Yoo D, Ellis GC, Gut P, Anderson RM, et al. Adenosine signaling promotes regeneration of pancreatic beta cells in vivo. Cell Metab (2012) 15(6):885-94. doi:10.1016/j.cmet.2012.04.018

71. Damond N, Thorel F, Moyers JS, Charron MJ, Vuguin PM, Powers AC, et al. Blockade of glucagon signaling prevents or reverses diabetes onset only if residual beta-cells persist. eLife (2016) 5:1-18. doi:10.7554/eLife.13828

72. Afelik S, Rovira M. Pancreatic beta-cell regeneration: facultative or dedicated progenitors? Mol Cell Endocrinol (2016). doi:10.1016/j.mce.2016.11.008
73. Kopp JL, Grompe M, Sander M. Stem cells versus plasticity in liver and pancreas regeneration. Nat Cell Biol (2016) 18(3):238-45. doi:10.1038/ncb3309

74. Cavelti-Weder C, Shtessel M, Reuss JE, Jermendy A, Yamada T, Caballero F, et al. Pancreatic duct ligation after almost complete beta-cell loss: exocrine regeneration but no evidence of beta-cell regeneration. Endocrinology (2013) 154(12):4493-502. doi:10.1210/en.2013-1463

75. Yin D, Tao J, Lee DD, Shen J, Hara M, Lopez J, et al. Recovery of islet beta-cell function in streptozotocin-induced diabetic mice: an indirect role for the spleen. Diabetes (2006) 55(12):3256-63. doi:10.2337/db05-1275

76. Bonner-Weir S, Trent DF, Honey RN, Weir GC. Responses of neonatal rat islets to streptozotocin: limited B-cell regeneration and hyperglycemia. Diabetes (1981) 30(1):64-9. doi:10.2337/diab.30.1.64

77. Rankin MM, Wilbur CJ, Rak K, Shields EJ, Granger A, Kushner JA. $\beta$-cells are not generated in pancreatic duct ligation-induced injury in adult mice. Diabetes (2013) 62(5):1634-45. doi:10.2337/db12-0848

78. Dalgin G, Prince VE. Differential levels of Neurod establish zebrafish endocrine pancreas cell fates. Dev Biol (2015) 402(1):81-97. doi:10.1016/j. ydbio.2015.03.007

79. Lancman JJ, Zvenigorodsky N, Gates KP, Zhang D, Solomon K, Humphrey RK, et al. Specification of hepatopancreas progenitors in zebrafish by hnflba and wnt2bb. Development (2013) 140(13):2669-79. doi:10.1242/dev.090993

80. Gardner DS, Tai ES. Clinical features and treatment of maturity onset diabetes of the young (MODY). Diabetes Metab Syndr Obes (2012) 5:101-8. doi:10.2147/DMSO.S23353

81. Michael MD, Kulkarni RN, Postic C, Previs SF, Shulman GI, Magnuson MA, et al. Loss of insulin signaling in hepatocytes leads to severe insulin resistance and progressive hepatic dysfunction. Mol Cell (2000) 6(1):87-97. doi:10.1016/ S1097-2765(05)00015-8

82. Zang L, Shimada Y, Nishimura Y, Tanaka T, Nishimura N. A novel, reliable method for repeated blood collection from aquarium fish. Zebrafish (2013) 10(3):425-32. doi:10.1089/zeb.2012.0862

83. Eames SC, Philipson LH, Prince VE, Kinkel MD. Blood sugar measurement in zebrafish reveals dynamics of glucose homeostasis. Zebrafish (2010) 7(2):205-13. doi:10.1089/zeb.2009.0640

84. O'Hare EA, Yerges-Armstrong LM, Perry JA, Shuldiner AR, Zaghloul NA. Assignment of functional relevance to genes at type 2 diabetes-associated loci through investigation of beta-cell mass deficits. Mol Endocrinol (2016) 30(4):429-45. doi:10.1210/me.2015-1243

85. Kimmel RA, Meyer D. Zebrafish pancreas as a model for development and disease. Methods Cell Biol (2016) 134:431-61. doi:10.1016/bs.mcb.2016.02.009

Conflict of Interest Statement: The authors declare that the research was conducted in the absence of any commercial or financial relationships that could be construed as a potential conflict of interest.

Copyright (๑) 2017 Maddison and Chen. This is an open-access article distributed under the terms of the Creative Commons Attribution License (CC BY). The use, distribution or reproduction in other forums is permitted, provided the original author(s) or licensor are credited and that the original publication in this journal is cited, in accordance with accepted academic practice. No use, distribution or reproduction is permitted which does not comply with these terms. 